\title{
Repetitive pulsed light treatment at certain interval on fresh-cut cantaloupe (Cucumis melo L. reticulatus cv. Glamour)
}

\begin{abstract}
This study was done in order to investigate the effect of repetitive pulsed light (RPL) treatment at certain interval on microbiological stability, quality and physicochemical changes of fresh-cut cantaloupes during storage. Fresh-cut cantaloupes packed in polypropylene bag were exposed to RPL treatment with fluences of $0.3,0.6,0.9$ and $1.2 \mathrm{~J} / \mathrm{cm}^{2}$ every $48 \mathrm{~h}$ up to 28 days of storage at $4 \pm 1{ }^{\circ} \mathrm{C}$. The microbiological quality, headspace gas composition, physical quality (firmness, fluid loss and colour), chemical quality $(\mathrm{pH}$, titratable acidity, total soluble solids, total phenolic content and ascorbic acid content) and microscopic observations of fresh-cut cantaloupes were determined during storage. No significant $(p>0.05)$ effect was observed for firmness, colour and total soluble solids of fresh-cut cantaloupes treated with RPL throughout the storage study. Repetitive PL treatment using $0.9 \mathrm{~J} / \mathrm{cm}^{2}$ was the most effective fluence for extending the shelf life of freshcut cantaloupes with extension by 20 days compared to control in term of microbiological quality while maintaining all quality parameters. Negative effect of single PL treatment (SPL) $\left(11.7 \mathrm{~J} / \mathrm{cm}^{2}\right)$ on tissue structure of fresh-cut cantaloupes during storage was minimised by applying RPL treatment $\left(0.9 \mathrm{~J} / \mathrm{cm}^{2}\right.$ for every $48 \mathrm{~h}$ interval $)$.
\end{abstract}

Keyword: Pulsed light; Repetitive; Fresh-cut cantaloupe; Non-thermal; Shelf life 